\title{
The Dilemma in the Diagnosis of Acute Scrotum: Clinical Clues for Differentiating between Testicular Torsion and Epididymo-Orchitis
}

\begin{abstract}
Kai-Jie Yu, MD; Ta-Min Wang, MD; Hsiao-Wen Chen, MD; Hsu-Han Wang, MD
Background: Acute painful scrotum is one of the most challenging urological emergencies. Irreversible parenchymal damage will develop if a testicle is twisted. The aim of the study was to determine the importance of different clinical clues to help differentiate the causes of this devastating condition.

Methods: The medical charts of teenagers with acute scrotal pain between January 2003 and December 2008 were reviewed retrospectively.

Results: $\quad$ Seventy-six patients were included in this study, including 47 initially suspected of having testicular torsion and 29 suspected of having epididymoorchitis. Testicular torsion was confirmed in 39 of the suspected 47 cases after surgical exploration. Twnety-one of these 39 testicular torsion patients underwent orchiectomy, and 18 were rescued and underwent orchiopexy. The mean pain duration was significantly longer in the orchiectomy group than the orchiopexy group (38.05 hours vs 14.14 hours, $p=0.009)$. In the testicular torsion group, fewer patients had elevated C-reactive protein levels no patients had pyuria, and the pain duration was shorter compared with the epididymo-orchitis group (5/11 vs $13 / 22$ [ $p=0.045]$, $0 / 28$ vs $8 / 28[p=0.004]$ and 27.0 vs 74.5 hours [ $p=0.0003]$, respectively). The sensitivity of color Dopper ultrasound in diagnosing testicular torsion and epididymo-orchitis was $84.09 \%$ vs $92.59 \%$. Logistic regression for multivariate analysis showed that left side manifestation and pain duration were significantly different between testicular torsion and epididymo-orchitis with odds ratios of $4.76, p$ $=0.020$ and $0.98, p=0.029$, respectively.
\end{abstract}

Conclusions: Pain duration and left side manifestation are independent risk factors of testicular torsion. Prompt surgical exploration should be done if testicular torsion is highly suspected.

(Chang Gung Med J 2012;35:38-45)

Key words: testicular torsion, pain duration, laterality

$\mathrm{T}$ he early and accurate diagnosis of testicular torsion remains a clinical challenge and it accounts for approximately $25 \%$ to $35 \%$ of patients presenting with acute scrotum. ${ }^{(1)}$ To date, no single reliable clinical feature or examination can give $100 \%$ diagnostic accuracy. ${ }^{(2)}$ In addition to testicular torsion, the origin

\footnotetext{
From the Department of Urology, Chang Gung Memorial Hospital at Linkou, Chang Gung University College of Medicine, Taoyuan, Taiwan.

Received: Dec. 14, 2010; Accepted: July 11, 2011

Correspondence to: Dr. Hsiao-Wen Chen, Department of Urology, Chang Gung Memorial Hospital at Linkou. 5, Fusing St., Gueishan Township, Taoyuan County 333, Taiwan (R.O.C.) Tel: 886-3-3281200 ext. 2130; Fax: 886-3-3285818;

E-mail: mhc1211@cgmh.org.tw
} 
of acute scrotal pain could be inflammatory disease, hydrocele, inguinal hernia, testicular tumor and underlying causes such as Schoenlein-Henoch purpura. Decisions about patient treatment are considerably influenced by an efficient diagnosis and optimal therapy suggestions, with most urologists opting for exploration of an acute scrotum rather than take any chance of misdiagnosis of spermatic cord torsion.

Testicular torsion has a lifetime incidence of approximately $1 / 4000$ males younger than 25 years. ${ }^{(3)}$ This disease affects a wide age range, and most commonly occurrs between the ages of 12 and 18 years, after which the incidence slowly decreases. ${ }^{(4)}$ The testes grow by a factor of five during puberty. This rapid growth, especially with respect to the stretched gubernacular attachments, which increases the propensity to fall forward and rotate, may explain this phenomenon. Testicular torsion usually occurs in the absence of a precipitating event; only $4 \%$ to $8 \%$ of cases result from trauma. ${ }^{(5)}$ Clinical studies where a varying degree of torsion is present, estimate testicular viability at $95 \%$ if symptoms have been present for less than 4 hours, $90 \%$ at less than 8 hours, $80 \%$ at less than 12 hours and $40 \%$ at less than 24 hours. If torsion has been present for more than 24 hours, testicular viability is estimated at less than $10 \%$.(6)

Intravaginal testicular torsion is typically associated with pain of sudden or insidious onset, nausea, and vomiting and is frequently followed by swelling of the ipsilateral scrotum. ${ }^{(7)}$ In addition to careful clinical evaluation, including history, symptoms and signs of acute scrotal pain, and measurements of laboratory data, Doppler sonography has been increasingly used in the evaluation of patients with suspicion of testicular torsion since it can be performed rapidly and in many studies the sensitivity and specificity were equal to those of a nuclear testicular scan. Although there are various potential causes of acute testicular pain, differentiation between testicular torsion and acute epididymo-orchitis is critical and demanding; differentiation is difficult in up to $50 \%$ of cases. ${ }^{(8)}$ Making the diagnosis is important as conservative treatment without surgery is used for acute epididymo-orchitis, opposite that of testicular torsion.

Taking into consideration that less than $30 \%$ of boys with acute scrotal pain have testicular torsion, ${ }^{(9)}$ accurate surgery indications aim to avoid unnecessary exploration (decrease the false positive rate) without missing testicular torsion. The aim of this retrospective study was to assess the reliability of laboratory examinations with Doppler ultrasound and clinical workups in the differentiation of epididymo-orchitis and testicular torsion in teenagers.

\section{METHODS}

Ninety-eight patients ten to twenty years old who were admitted between 1993 and 2008 via the emergency department with acute scrotal pain were included. After a history, and physical examination and measurements of the hemogram, urinalysis and biochemistry, a Doppler sonographic $7.5 \mathrm{MHz}$ linear array transducer (ALOKA 5500) was used for image evaluation. The ultrasound procedures were performed by a senior urologic resident or under his or her supervisor. If Doppler investigation showed reduction of central arterial perfusion on the diseased side after comparison with the opposite side in the longitudinal and transverse views, or the cause of acute scrotal pain was clinically uncertain, surgical exploration was performed after complete informed consent. The pain duration was defined as the time between onset of pain and the time the patient came to the emergency department. Patients with incomplete medical records, including absent laboratory data or an unclear clinical history were excluded. A total of 20 patients were excluded from this study because of incomplete data. Another 2 patients who had an uncertain pain duration on the medical chart were also excluded. Six patients were included who did not have complete ultrasound reports, including 1 with hydrocele, 3 with epididymo-orchitis and 2 with testicular torsion. The 6 patients with incomplete ultrasound reports were included in the final count of patients, since you mention these incomplete reports before the final patient count, it makes it seem as if these 6 patients were excluded. Preoperative ultrasonographic results and laboratory data were correlated and compared with the surgical findings, and 76 patients were finally included. The data were analyzed by the Mann-Whitney U test and Fisher's exact test, respectively, for pain duration and laterality between testicular torsion and epdidymo-orchitis. The Pearson chi-square test was applied for the association of leukocytosis (WBC $>10000 / \mathrm{uL}$ ) and Creactive protein elevation (CRP $>5 \mathrm{mg} / \mathrm{L}$ ) between testicular torsion and epididymo-orchitis. Fisher's 
exact test was applied for the association of pyuria (WBC $>30 / \mathrm{uL}$ on urinalysis) between these two groups. A $p$ value $<0.05$ was defined as a significant difference. A logistic regression test was applied for multivariate analysis. The statistical analysis was managed with SPSS $15^{\text {th }}$ edition.

\section{RESULTS}

Seventy-six teenagers were included. All boys had acute scrotal pain, swelling and tenderness. Forty seven of these 76 patients $(61.8 \%)$, who were highly suspected of having testicular torsion after the history, laboratory and pre-operative scrotal Doppler ultrasound examination underwent surgical exploration. Testicular torsion was confirmed by surgery in 39 of these 47 initially suspected cases. Two of the 8 other patients who underwent exploration had torsion of the testicular appendix, 2 had epididymoorchitis, 2 had a scrotal hematoma, 1 had a hydrocele, and one had testicular lymphoma. The diagnosis of non-torsion wasreconfirmed in the 29 patients who were managed conservatively, and follow-up ultrasound examinations showed normal central perfusion as well as normal echogenic patterns and sizes of both testes during follow-up in the outpatient department.

In 18 of the 39 boys with a definite diagnosis of testicular torsion, the involved testes were salvaged after detorsion with a warm water bath, with an ipsilateral orchiopexy in 3 and bilateral orchiopexy in 15. The other 21 ischemic testes with hemorrhagic infarction were resected with a routine orchiopexy on the contralateral side. The mean pain durations were significantly different between those with salvaged and unsalvaged testes. Boys in whom the twisted testicle was nonviable on exploration experienced a mean 38.1 hours of pain ( 2 - 336 hours), whereas boys in whom the twisted testis was salvaged experienced a mean 14.1 hours of pain ( $2-72$ hours) ( $p=$ 0.009) (Table 1 and Fig. 1). The pathologic results of the orchiectomy group showed hemorrhagic infarct or hemorrhagic necrosis without other abnormal findings.

Table 2 and Fig. 2 compare boys with testicular torsion andepididymo-orchitis. There was no difference in mean age (14.4 years v.s. 14.0 years, $p=$ $0.63)$. Left side torsion was more common than right side torsion, but there was no apparent laterality pre-
Table 1. Comparison between Orchiectomy and Orchiopexy Groups

\begin{tabular}{|c|c|c|c|}
\hline & $\begin{array}{c}\text { Orchiectomy } \\
\mathrm{N}=21\end{array}$ & $\begin{array}{l}\text { Orchiopexy } \\
\qquad \mathrm{N}=18\end{array}$ & $p$ value \\
\hline Age (year) & 14.2 & 14.6 & $0.647 *$ \\
\hline Laterality (Left/Right/Bilateral) & $17 / 4 / 0$ & $14 / 2 / 2$ & \\
\hline Duration of pain (hour) & 38.1 & 14.1 & $0.009 *$ \\
\hline \multicolumn{4}{|l|}{ Physical examination } \\
\hline Erythema & $21 / 21$ & $18 / 18$ & $\mathrm{NA}^{\dagger}$ \\
\hline Swelling & $21 / 21$ & $18 / 18$ & $\mathrm{NA}^{\dagger}$ \\
\hline Tenderness & $21 / 21$ & $18 / 18$ & $\mathrm{NA}^{\dagger}$ \\
\hline \multicolumn{4}{|l|}{ Laboratory findings } \\
\hline $\begin{array}{l}\text { Leukocytosis } \\
(\mathrm{WBC}>10000 / \mathrm{LL})\end{array}$ & $\begin{array}{l}21 / 39 \\
(53 \%)\end{array}$ & $\begin{array}{l}19 / 30 \\
(63 \%)\end{array}$ & $0.656^{\dagger}$ \\
\hline $\mathrm{CRP}>5 \mathrm{mg} / \mathrm{L}$ & $\begin{array}{c}4 / 6 \\
(67 \%)\end{array}$ & $\begin{array}{c}1 / 5 \\
(20 \%)\end{array}$ & $0.122^{\dagger}$ \\
\hline $\begin{array}{l}\text { Pyuria } \\
\text { (Urine } \mathrm{WBC}>30 / \mathrm{uL} \text { ) }\end{array}$ & $\begin{array}{l}0 / 15 \\
(0 \%)\end{array}$ & $\begin{array}{l}0 / 13 \\
(0 \%)\end{array}$ & $\mathrm{NA}^{\dagger}$ \\
\hline
\end{tabular}

Abbreviations: CRP: C-reactive protein; WBC: white blood cells; NA: not available because contents are constant; *: Nonparametric Mann-Whitney test; $\uparrow$ : Pearson Chi-square test.

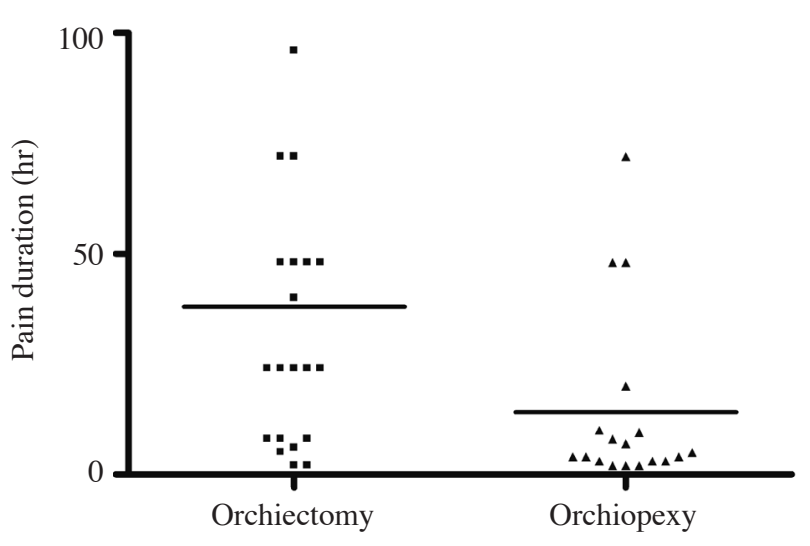

Fig. 1 Scatter plot comparing pain duration between patients who underwent orchiectomy and orchiopexy in the testicular torsion group ( $p=0.009$ ). 
Table 2. Comparison between Testicular Torsion and Epididymo-orchitis Groups

\begin{tabular}{|c|c|c|c|}
\hline & $\begin{array}{c}\text { Testicular } \\
\text { torsion } \\
\mathrm{N}=39\end{array}$ & $\begin{array}{l}\text { Epididymo- } \\
\text { orchitis } \\
\qquad \mathrm{N}=31\end{array}$ & $p$ value \\
\hline Age (year) & 14.4 & 14.0 & $0.647 *$ \\
\hline $\begin{array}{l}\text { Laterality } \\
\text { (Left/Right/Bilateral) }\end{array}$ & $32 / 6 / 1$ & $14 / 14 / 3$ & \\
\hline Duration of pain (hour) & 27.0 & 74.5 & $0.0003 *$ \\
\hline \multicolumn{4}{|l|}{ Physical examination } \\
\hline Erythema & $39 / 39$ & $31 / 31$ & $\mathrm{NA}^{\dagger}$ \\
\hline Swelling & $39 / 39$ & $31 / 31$ & $\mathrm{NA}^{\dagger}$ \\
\hline Tenderness & $39 / 39$ & $31 / 31$ & $\mathrm{NA}^{\dagger}$ \\
\hline \multicolumn{4}{|l|}{ Laboratory findings } \\
\hline $\begin{array}{l}\text { Leukocytosis } \\
(\mathrm{WBC}>10000 / \mathrm{uL})\end{array}$ & $\begin{array}{l}12 / 21 \\
(57 \%)\end{array}$ & $\begin{array}{c}9 / 18 \\
(50 \%)\end{array}$ & $0.656^{\dagger}$ \\
\hline $\mathrm{CRP}>5 \mathrm{mg} / \mathrm{L}$ & $\begin{array}{c}5 / 11 \\
(46 \%)\end{array}$ & $\begin{array}{l}13 / 22 \\
(59 \%)\end{array}$ & $0.045^{\dagger}$ \\
\hline $\begin{array}{l}\text { Pyuria } \\
\text { (Urine WBC > 30/uL) }\end{array}$ & $\begin{array}{l}0 / 28 \\
(0 \%)\end{array}$ & $\begin{array}{c}8 / 28 \\
(29 \%)\end{array}$ & $0.004^{\dagger}$ \\
\hline
\end{tabular}

Abbreviations: CRP: C-reactive protein; WBC: white blood cells; NA: not available because contents are constant; *: Nonparametric Mann-Whitney test; $\uparrow$ : Pearson Chi-square test.

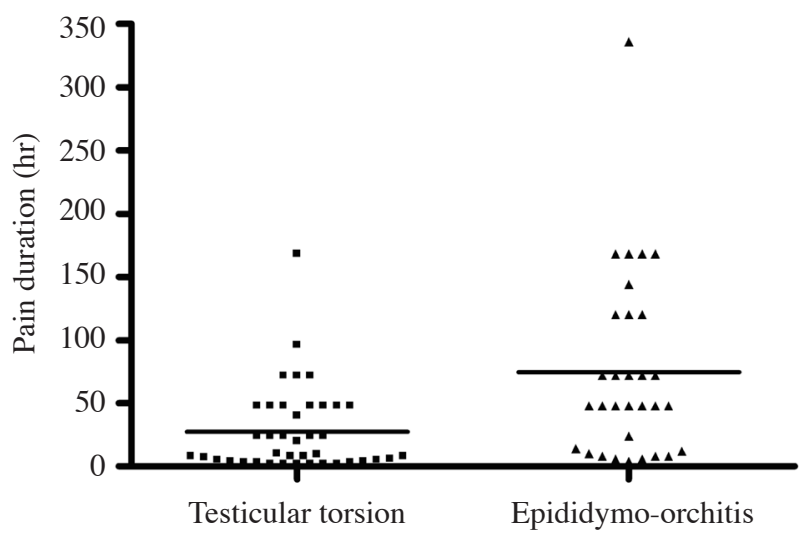

Fig. 2 Scatter plot comparing pain duration between atients with testicular torsion and epididymo-orchitis $(p=0.0003)$. dominance in the epididymo-orchitis group ( $p=$ $0.003)$. The pain duration was significantly different between the two groups. Boys with suspected testicular torsion confirmed by surgery experienced a mean 27.0 hours of pain $(2-336$ hours $)$, whereas boys in whom epididymo-orchitis was impressed experienced an average 74.5 hours of pain (4-336 hours) ( $p=0.0003)$. All patients presented with acute scrotal swelling, reddening and tenderness at the initial physical examination. Laboratory assessments showed more leukocytosis in the epididymo-orchitis group but no significant difference when compared with the testicular torsion group $(p=0.429)$. The CRP was elevated in 5 of $11(46 \%)$ in the testicular torsion group and in 13 of $22(59 \%)$ in the epididymo-orchitis group, $p=0.045$. Pyuria occured significantally more often in the epididymo-orchitis group $(p=0.004)$. Doppler ultrasound revealed increased blood flow signals in 2 patients in the suspected testicular torsion group. However, the history and clinical presentation could not exclude testicular torsion and the families decided on surgical exploration after discussion. Exploration showed epididymo-orchitis. The sensitivity of color Doppler ultrasound to diagnose torsion and epididymo-orchitis was $84.09 \%$ and $92.59 \%$ from our retrospective results. Logistic regression for multivariate analysis showed that left side manifestation and pain duration were significantly different between the testicular torsion and eididymo-orchitis groups. Left side testicular pain had an odds ratio of 4.76 for testicular torsion, $p=$ 0.020 . The odds ratio for pain duration was $0.98, p=$ 0.029. Elevation of CRP and pyuria were not statistically different between the two groups in advanced analysis (Table 3 ).

\section{DISCUSSION}

The diagnosis and treatment of patients presenting with acute scrotum continues to be one of the most challenging issues in pediatric urology. ${ }^{(10)}$ The present data suggest that obligatory emergency scrotal exploration is not necessary in more than $75 \%$ of cases presenting with acute scrotum. ${ }^{(1)}$ The need for urgent exploration of the twisted testis relates to the possible viability of the testes and for two further reasons. First, the anatomical abnormality responsible for the torsion (bare area in the classification of intravaginal type torsion) is often bilateral and there- 
Table 3. Multiple Logistic Regression for Likelihood of Testicular Torsion

\begin{tabular}{|c|c|c|c|c|}
\hline \multirow{2}{*}{ Parameter } & \multirow{2}{*}{$\begin{array}{l}\text { Odds } \\
\text { Ratio }\end{array}$} & \multicolumn{2}{|c|}{$95 \%$ Confidence interval } & \multirow{2}{*}{$p$ value } \\
\hline & & Lower & Upper & \\
\hline \multicolumn{5}{|l|}{ Pain laterality } \\
\hline $\begin{array}{l}\text { Right side or } \\
\text { bilateral pain }\end{array}$ & 1.000 & (reference) & & \\
\hline Left side pain & 4.769 & 1.276 & 17.823 & 0.020 \\
\hline $\begin{array}{l}\text { Pain duration } \\
\text { (hours from onset to ER) }\end{array}$ & 0.986 & 0.975 & 0.999 & 0.029 \\
\hline $\mathrm{CRP} \leq 5 \mathrm{mg} / \mathrm{L}$ & 1.000 & (reference) & & \\
\hline $\mathrm{CRP}>5 \mathrm{mg} / \mathrm{L}$ & 0.295 & 0.072 & 1.214 & 0.091 \\
\hline Urine $\mathrm{WBC} \leq 30 / \mathrm{uL}$ & 1.000 & (reference) & & \\
\hline Urine $\mathrm{WBC}>30 / \mathrm{uL}$ & 0.000 & 0.000 & - & 0.999 \\
\hline
\end{tabular}

Abbreviations: ER: emergency room; CRP: C-reactive protein; WBC: white blood cells.

fore, the contralateral testis is usually routinely fixed at exploration. Second, several studies have disclosed that if a twisted testis is not removed, a reduced sperm count is not uncommon. ${ }^{(11-13)}$

In our study, the pain duration was significantly different between groups. Testicular ischemia typically presents with sharp pain and epididymo-orchitis presents with indolent or slowly progressive pain. Logistic regression analysis showed that the chance of testicular torsion decreased by $2 \%$ when the pain duration increased by 1 hour. However, patients or parents are often not so sure about the exact time of onset. Also, spontaneous detorsion and recurrent torsion are not uncommon, which could make the exact time of onset vague. A pain scale with a range of 1 to 10 to differentiate the severity of scrotal pain, might correlate with the pain duration.

Physical examination could not differentiate torsion from infection, possibly because of loss of detailed records in charts in the emergency department. A negative Prehn's sign, a high-riding testicle and loss of the cremasteric reflex might help in differentiation. In addition, logistic regression analysis showed the odds ratio for left side scrotal pain was 4.76, which means left side testicular torsion predominates. This could be anatomically related to the greater length of the left side spermatic cord which could have a higher incidence of twisting. ${ }^{(14)}$

Further detailed records should be emphasized in the next prospective study. Laboratory study showed that patients with epididymo-orchitis had higher rates of elevated inflammatory parameters, although there was no significant difference in multivariate analysis. However, not all patients completed all the laboratory examinations and further laboratory criteria should be used for comparison in further prospective study. Ultrasound has been increasingly used in the clinical evaluation of testicular pathology. ${ }^{(15)}$ Ultrasound has proved to be a somewhat more desirable modality than since it can be performed more rapidly and in many studies, the sensitivity and specificity were equal to those of a nuclear testicular scan. ${ }^{(16)}$

For complete and comparable results, records should include echogenicity, structure and volumetry of the testis and epididymis on both sides, the resistance index (RI) and assessment of central and peripheral blood flow signals in the testicles in power and color Doppler sonography. In an inflammatory process, the RI usually declines, and with torsion, higher counts are to be expected. Special attention should be paid to the fact that spontaneous reduction with repeated torsion can reveal the picture as reactive hyperperfusion of the testicular parenchyma. ${ }^{(17)}$ A further exception is epididymo-orchitis complicated by testicular infarction, which probably arises as a consequence of edema compromising venous drainage leading to thrombosis of the pampiniform plexus. An experienced urologist might observe that a reversal of diastolic flow in the testicular artery is characteristic of venous thrombosis. Nonetheless, if facilities allow, scintigraphy may give some more information, by showing increased peripheral flow and central hypoperfusion, whereas with torsion peripheral flow will be normal.

The timing of surgical exploration for acute scrotum is controversial. Murphy et al revealed the wisdom of liberal scrotal exploration in all acute scrotum cases. ${ }^{(18)}$ Gunther et al suggested that if Doppler sonography is performed correctly as a standard procedure, it may replace surgical exploration, which would only be indicated in cases of doubt. ${ }^{(1)}$ They suggested that the diagnostic benefit of routine surgical evaluation is small in comparison with the risks of aspiration and wound infection and that total 
costs may be reduced by replacing surgery with ultrasound. Another controversial issue is whether twisted testicles need to be removed and whether a retained ischemic testicle may expose the patient to the potential risk of autoimmunization and consequent damage to the contralateral gonad. ${ }^{(19)}$ Some believe that because the degree of irreversibility of tissue damage can not be definitely judged intraoperatively, extraction of the testis should only be performed in cases of strongly evident destruction. ${ }^{(1)}$ However, there are some reports of failed suture fixation, combined with concerns that violation of the blood-testis barrier may adversely affect fertility and increase the risk of testicular malignancy. ${ }^{(20)}$ Several groups have reported decreases in testicular function even after removal of the twisted testes, thus postulating that the ipsilaterally torsed spermatic cord releases substances that act remotely on the contralateral testis. ${ }^{(21)}$ Therefore, further prospective study with long-term clinical follow-up for these patients is mandatory.

Recent studies have advocated improvement in the detection of testicular blood flow with the use of 'power' Doppler techniques. Bader et al demonstrated that whereas color Doppler ultrasound could not consistently detect flow until the age of 12 years, power Doppler could detect it from the age of 8 years. ${ }^{(22)}$ The sensitivity of color Doppler ultrasound to diagnose torsion and epididymo-orchitis was $84.09 \%$ and $92.59 \%$ in our retrospective results. Nonetheless, ultrasound is not sufficient for diagnosing testicular torsion. Interestingly, the pain duration was significantally shorter in the torsion patients compared with the epididymo-orchitis patients. This could be a clue to increase the accuracy of diagnosis, even though the tendency of pain need be descript in scale. From our review, there is no single diagnostic test that can reliably distinguish testicular torsion from other causes of testicular pain. Patients highly suspected of having testicular torsion from Doppler ultrasound with associated significant clinical clues such as a short pain duration or manifestation on the left side should be critically treated as emergency cases to avoid irreversible damage to the testis.

\section{Conclusions}

There is no single clinical feature that can reliably distinguish testicular torsion from other causes of testicular pain, especially epididymo-orchitis.
Epididymo-orchitis was highly suspected in patients with indolent pain combined with abnormal laboratory findings, especially CRP elevation and pyuria. Testicular torsion was highly suspected when patients with acute scrotum presented with silence of blood flow signals on color Doppler ultrasound, associated with acute onset of pain for a short duration, or manifestation on the left side. Prompt surgical exploration should be performed to salvage the twisted testicle as soon as possible.

\section{REFERENCES}

1. Gunther P, Schenk JP, Wunsch R, Holland-Cunz S, Kessler U, Troger J, Waag KL. Acute testicular torsion in children: the role of sonography in the diagnosis workup. Eur Radiol 2006;16:2527-32.

2. Kalfa N, Veyrac C, Lopez M, Lopez C, Maurel A, Kaselas C, Sibai S, Arena F, Vaos G, Bréaud J, Merrot T, Kalfa D, Khochman I, Mironescu A, Minaev S, Avérous M, Galifer RB. Multicenter assessment of ultrasound of the spermatic cord in children with acute scrotum. J Urol 2007; 177:297-301

3. Blaivas M, Batts M, Lambert M. Ultrasound diagnosis of testicular torsion by emergency physicians. Am J Emerg Med 2000;18:198-200.

4. Tumeh SS, Benson CV, Richie JP. Acute diseases of the scrotum. Semin Ultrasound CT MRI 1991;2:115-30.

5. Ringdahl E, Teague L. Testicular torsion. Am Fam Physician 2006;74:1739-43.

6. Scheldon CA. Undescended testes and testicular torsion. Surg Clin North Am 1985;65:1303-29.

7. Rabinowitz R, Hulbert WC. Acute scrotal swelling. Urol Clin North Am 1995;22:101-5.

8. Hricak H, Jeffery RB. Sonography of acute scrotal abnormalities. Radiol Clin North Am 1983;21:595-603.

9. Stehr M, Boehm R. Critical validation of color Doppler ultrasound in diagnostics of acute scrotum in children. Eur J Pediatr Surg 2003;13:386-92.

10. Mor Y, Pinthus JH, Nadu A, Raviv G, Golomb J, Winkler $\mathrm{H}$, Ramon J. Testicular fixation following torsion of the spermatic cord - does it guarantee prevention of recurrent torsion events? J Urol 2006;175:171-4.

11. Bartsch G, Frank S, Marberger H Mikuz G. Testicular torsion: late results with special regard to fertility and endocrine function. J Urol 1980;124:375-8.

12. Barkley C, York JP, Badalament RA Nesbitt JA, Smith JJ, Drago JR. Testicular torsion and its effects on contralateral testicle. Urology 1993;41:192-4.

13. Ryan PC, Whelan CA, Gaffney EF, Fitzpatrick JM. The effect of unilateral experimental testicular torsion on spermatogenesis and fertility. Br J Urol 1988;62:359-66.

14. Williamson RCN. Torsion of the testis and allied condi- 
tions. Br J Surg 1976;63:465-76.

15. Sidhu PS. Clinical and imaging features of testicular torsion. Clin Radiol 1999;54:343-52.

16. Kaye JD, Shapiro EY, Levitt SB, Friedman SC, Gitlin J, Freyle J, Palmer LS. Parenchymal echo texture predicts testicular salvage after torsion: potential impact on the need for emergent exploration. J Urol 2008;180:1733-6.

17. Jee WH, Choe BY, Byun JY Shinn KS, Hwang TK. Resistive index of the intrascrotal artery in scrotal inflammatory disease. Acta Radiol 1997;38:1026-30.

18. Murphy FL, Fletcher L, Peace P. Early scrotal exploration in all cases is the investigation and intervention of choice in the acute paediatric scrotum. Pediatr Surg Int
2006;22:413-6.

19. Puri P, Barton D, O'Donnell B. Prepubertal testicular torsion: subsequent fertility. J Pediatr Surg 1985;20:598-601.

20. Frank JD, O'Brien M. Fixation of the testis. BJU Int 2002;89:331-3.

21. Salman AB, Kilinc K, Tanyel FC. Torsion of only spermatic cord in the absence of testis and/or epididymis results in contralateral testicular hypoxia. Urol Res 1997;25:413-5.

22. Bader TR, Kammerhuber F, Herneth AM. Testicular blood flow in boys as assessed at color Doppler and power Doppler sonography. Radiology 1997;202:559-64. 


\title{
診斷急性陰囊疼痛之困難 : 更多區別睪丸扭轉與睪丸附睪丸炎的臨床線索
}

\author{
虞凱脌 王大民陳孝文 王敘涵
}

背景: 急性睪丸疼痛對泌尿科醫師來説是最具挑戰的急診疾病。若是無法在睪丸缺血的黄 金時間内手術, 將會造成無法回復之傷害。本文之目的希望能找出對睪丸扭轉診斷 友幫助之重要臨床線索。

方 法: 回朔蒐集自 2003 年 1 月至 2008 年 12 月所有急性睪丸疼痛之青少年 (10 歲至 20 歲) 病患資料。

結 果: 共有 76 位病患收案, 包含 47 位懷疑睪丸扭轉及 29 位懷疑睪丸一副睪丸發炎。4 7 位 接受開刀之病患中, 有 39 位確認是睪丸扭轉。而在此 39 位病患中, 有 21 位接受睪 丸切除, 有 18 位睪丸回復併接受睪丸固定手術。此二組疼痛時間有明顯差異 (接受 睪丸切除者爲 38.05 小時 V.s 接受睪丸固定者爲 14.14 小時, $p=0.009$ )。在實驗室檢 驗資料方面, CRP 及膿尿在雨組間亦有統計學上之差異, 分別爲 $5 / 11$ 比上 $13 / 22, p$ 值爲 0.045 及 $0 / 28$ 比上 $8 / 28, p$ 值爲 0.004 。疼痛時間在睪丸扭轉者爲 27.0 小時而在 睪丸一副睪丸發炎者爲 74.5 小時, 超音波診斷睪丸扭轉與急性睪丸附睪丸發炎之敏 感性爲 $84.09 \%$ 與 92.59\%。多變項罯輯性回歸分析顯示睪丸扭轉病患好發於左側陰囊 及疼痛持續時間較長, 於統計學上與急性睪丸附睪丸發炎有明顯差異 $(p=0.003$ 及 $0.0003)$ 。

結 論: 疼痛時間及左側病灶爲獨立之風險因素。若是急性睪丸疼痛高度疑似睪丸扭轉, 建 議儘早開刀以期能挽救缺血之睪九。

(長庚醫誌 2012;35:38-45)

關鍵詞：睪丸扭轉, 疼痛時間, 疼痛側位

長庚醫療財團法人林口長庚紀念醫院 泌尿科 ; 長庚大學 醫學院

受文日期：民國99年12月14日；接受刊載：民國100年7月11日

通訊作者: 陳孝文醫師, 長庚醫療財團法人林口長庚紀念醫院 泌尿科。桃園縣333龜山鄉復興街5 號。

Tel: (03)3281200轉2103; Fax: (03)3285818; E-mail: mhc1211@cgmh.org.tw 